\title{
Personlighetsforstyrrelser i klinisk praksis
}

Personlighetsforstyrrelser omfatter flere tilstander og atferdsmønstre som er stabile. Disse representerer ekstreme eller betydningsfulle avvik fra hvordan et gjennomsnittsindivid i en gitt kultur sanser, tenker, føler og forholder seg til andre, og det er vanlig med betydelige subjektive plager og/eller problemer i familiære og yrkesmessige sammenhenger.

Wilberg og medarbeidere har i dette nummer av Tidsskriftet en artikkel om behandling av pasienter med personlighetsforstyrrelser i psykiatrisk/psykologisk avtalepraksis (1). Studien viser at det er en del utfordringer: Noen avbrøt behandlingen, og det var også vanskeligheter knyttet til rusmisbruk og annen utagerende atferd. Selv motiverte og erfarne terapeuter opplevde at mange pasienter uteble fra timer, utagerte eller droppet helt ut av opplegget. Samtidig var mange pasienter tilfreds med behandlingen.

Mens det tidligere har vært en tendens til å betrakte disse tilstandene som relativt behandlingsrefraktære, har det i løpet av de siste tiårene vært en økende interesse blant forskere for å utvikle effektiv behandling for personlighetsforstyrrelser. Denne har variert fra sykehusinnleggelse via dagopphold til psykoterapi hos avtalespesialister utenfor sykehus. Behandling hos avtalespesialister gir mulighet for en kontinuitet man ikke så lett kan få ved sykehusbehandling eller distriktspsykiatriske sentre.

Imidlertid er det stor variasjon i problematikk og utfordringer ved forskjellige personlighetsforstyrrelser. Blant de spesifikke personlighetsforstyrrelsene (F60-gruppen i ICD 10) er det stor forskjell på de avhengige og unnvikende, de ustabile eller antisosiale og de paranoide eller schizoide. Der noen trenger støtte og oppmuntring, trenger andre også konfrontasjon og grensesetting. Mange har kompliserende atferd med rusmisbruk og/eller utagering. Dette kan være vanskelig å håndtere i en psykiatrisk/psykologisk avtalepraksis, og før man går inn i en slik behandling er det nødvendig med en grundig vurdering av hvorvidt pasienten er egnet og motivert for psykoterapi. Pasienter som er mer ustabile og utagerende trenger trolig mer sammensatte behandlingstilbud.

Pasienter med emosjonelt ustabil personlighetsforstyrrelse (F 60.3) er en særlig behandlingsmessig utfordring, blant annet som følge av den sterke tendensen til å reagere emosjonelt og ha skiftende motivasjon. Det er etter hvert utviklet flere metoder for behandling av disse. De viktigste er dialektisk atferdsterapi, mentaliseringsbasert terapi, behandling med fokus på overføring og overførings- og skjemafokusert terapi (2). Hovedkonklusjonen er at psykoterapi er virksomt, men det er ikke grunnlag for noen sterk anbefaling av den ene metoden fremfor den andre. I en norsk studie ga mentaliseringsbasert terapi bedre resultater enn tradisjonell psykoterapi (3). Et viktig område for intervensjonen er å utvikle evnen til å integrere tanke og emosjon. Metoden førte til mindre frafall fra behandlingen, mindre symptomer og bedre psykososial fungering enn sammenlikningsgruppen som fikk mer tradisjonell psykoterapi.

Det er behov for at psykiatere og psykologer utvikler spisskompetanse i forhold til noen diagnostiske undergrupper. En terapeut kan være en utmerket behandler for en pasient med avhengig og unnvikende personlighetsforstyrrelse, men kanskje ha problemer i forhold til pasienter som er utagerende og trenger grensesetting. Det kan skyldes at det kreves forskjellig tilnærming, men kanskje mest personlige egenskaper hos terapeuten.
I en tid med økende forventning om effektivitet og kort behandlingstid blir det ofte glemt at mange tilstander er kroniske og dermed ikke kan behandles raskt. Mange pasienter med personlighetsforstyrrelser har hatt en vanskelig oppvekst preget av ustabilitet, uhensiktsmessige stimuli og uklare grenser. Når en person gjennom mange av de mest formende årene i livet har utviklet et problematisk forhold til seg selv og andre, er det urealistisk å tro at en behandler skal kunne rette opp dette i en korttidsintervensjon.

I den aktuelle undersøkelsen var en tredel av pasientene fortsatt $i$ behandling etter tre år (1). Det gjennomsnittlige antall timer $\mathrm{i}$ behandling var 43 timer. Kostnadene ved dette er omtrent som for 1-2 ukers opphold i en psykiatrisk døgnavdeling. Utgifter til langtids psykoterapi er begrenset, og mulighetene for innsikt, vekst og utvikling er større enn gjennom et kortvarig akuttopphold.

Somatiske helseproblemer er vanlig hos mange pasienter med personlighetsforstyrrelse, ikke minst som følge av rusmisbruk, skader og ulykker. Disse behandles derfor i somatiske sykehusavdelinger og ikke minst i allmennpraksis og på legevakt. Fastlegene er et vesentlig ledd i behandlingskjeden ved å integrere behandlingstiltak og være stabile kontakter. Kompetanse er derfor nødvendig også i denne delen av helsevesenet. Fastlegene kan ha nytte av veiledning fra psykiater, mens man kan få hjelp fra den psykiatriske konsultasjonstjenesten (liaison) ved somatiske avdelinger.

Mange av disse pasientene blir uføretrygdet i ung alder etter å ha utviklet kroniske tilstander med økende psykososiale og somatiske komplikasjoner. Mange bidrar også sterkt til den betydelige dødeligheten som følge av rusmisbruk, ulykker eller selvmord. Ofte vil nok behandlingen først og fremst dreie seg om å forsøke å bremse en negativ utvikling. Etter hvert som det oppstår somatiske komplikasjoner får også andre deler av helsevesenet en stadig større oppgave.

Til tross for alt dette er det grunn til en behersket optimisme når det gjelder behandling av pasienter med personlighetsforstyrrelse. Mulighetene synes å bli stadig bedre for motiverte pasienter, særlig når det utvikles spesifikke tiltak som er tilpasset ulike undergrupper.

\section{Øivind Ekeberg}

oivind.ekeberg@uus.no

Øivind Ekeberg er spesialist i psykiatri, overlege og leder av forskningsenheten (FOU) ved Akuttmedisinsk avdeling, Oslo universitetssykehus, Ullevål og professor II ved Avdeling for atferdsvitenskap, Institutt for medisinske basalfag, Universitetet i Oslo.

Forfatter har fylt ut ICMJE-skjemaet og oppgir ingen interessekonflikter.

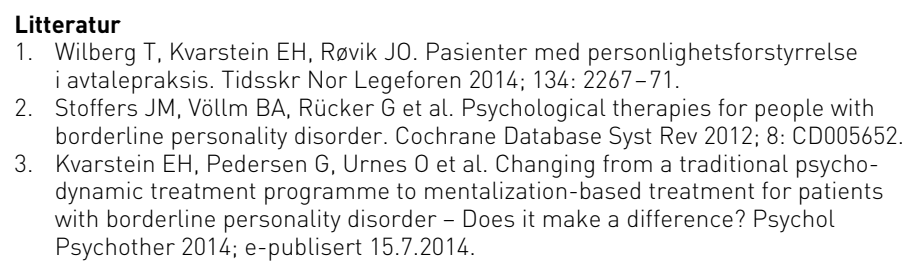

